\title{
Leadership capability and the effectiveness of state-owned enterprise
}

\author{
(C) Higher Education Press and Springer-Verlag 2008
}

\begin{abstract}
In this paper, a conceptual model of state-owned enterprises(SOEs) is built up based on several different perspectives, such as property right approach, management approach, and leadership capability approach. Using the data of World Bank's survey on 1500 Chinese firms from five cities in 2001, the authors conclude that differences in leadership capabilities represented by leaders' demographic characteristics exert influences on enterprise efficiency. Specifically, the degree of such influences in the SOEs is much higher than that of in the non-state-owned enterprise(NSOE) due to reasons of property right problems and insufficient incentive mechanisms in SOEs. Furthermore, the authors argue that empowering reforms will lead to phenomenon of differentiation in SOEs, causing huge differences in enterprise performances in the long run.
\end{abstract}

Keywords leadership capability, firm effectiveness, empowering reform

摘要 基于产权学派、管理学派及领导者能力学派的观点建立概念模型, 利用世界 银行 2001 年对我国 5 个城市 1500 家企业的调查数据, 采用计量统计方法对数据进 行分析, 得出由领导者传记性特征所代表的能力差异会影响企业效率的结论。同时, 由于产权和激励机制方面的不足, 这种影响程度在国有企业内部会远大于非国有企 业。放权式改革政策会导致国有企业间的分化现象, 最终导致企业间的经营业绩出 现很大差异。

Received November 20, 2007

JING Runtian $(\bowtie)$, LIU Yuhuan

School of Management, University of Electronic Science and Technology of China, Chengdu 610054, China

E-mail: rtjing@uestc.edu.cn

LIU Ping

Chengdu College, University of Electronic Science and Technology of China, Chengdu 611731, China 
关键词 领导者能力, 企业效率, 放权式改革

\section{Introduction}

SOEs are enterprises owned and directly controlled by the state. To those countries under economic reform, SOEs are always one of the biggest challenges. Since 1980s, Chinese SOE reform has been carried out along the direction of empowerment and marketization. Attempted reform models include the contracting system, chartering system and capital operative responsibility system. At present, China is in a critical phase of establishing a modern enterprise system. Frequently asked questions include why China's SOEs suffer from such low enterprise efficiency? What are the causes behind this inefficiency? Jefferson, Rawski and Zheng(1999) pointed out that the resources and equipment of SOEs are not inferior to other types of enterprises (as shown in Table 1). Likewise, Huang's (2003) data showed that SOEs have advantages in resources over most of NSOEs, slightly worse only than foreign invested companies/foreign enterprises.

As owned by state government, SOEs have a lot of advantages in obtaining license contract for patented technologies, technology service and consultation, and in equipment import affairs, which are favorable for technology innovation in these SOEs. From 1981 to 1995, China invested 53.5 billion dollars in technology import, $72 \%$ of which were invested in turn-key projects. Though as the biggest beneficiaries of these imported projects, most SOEs do not make full use of these advanced foreign technologies and equipments owing to inefficient managerial systems. A follow-up investigation on 1890's turn-key projects showed that only $31 \%$ of these projects reached or surpassed pre-set profit goals. Huang(2003) SOEs also have unmatchable advantages over other NSOEs in gaining governmental financial supports. Data show that $94 \%$ of the loans of the four biggest commercial banks in China have been granted to SOEs, 3\% to collective enterprises, $3 \%$ to foreign-invested companies. Private owned enterprises get only $0.1 \%$ of the total commercial loans. A possible explanation is that though financial policy allows medium and small sized credit cooperatives to grant loans to private-owned enterprises, these enterprises have great difficulties in actually getting the loans.

Hence, when explaining Chinese SOE's low efficiency of resource advantages utilization, we can exclude factors of HR, material resources or policy environment. Both the property right school and the management school of thoughts hold that problematic mechanisms cause low efficiency. To solve the 


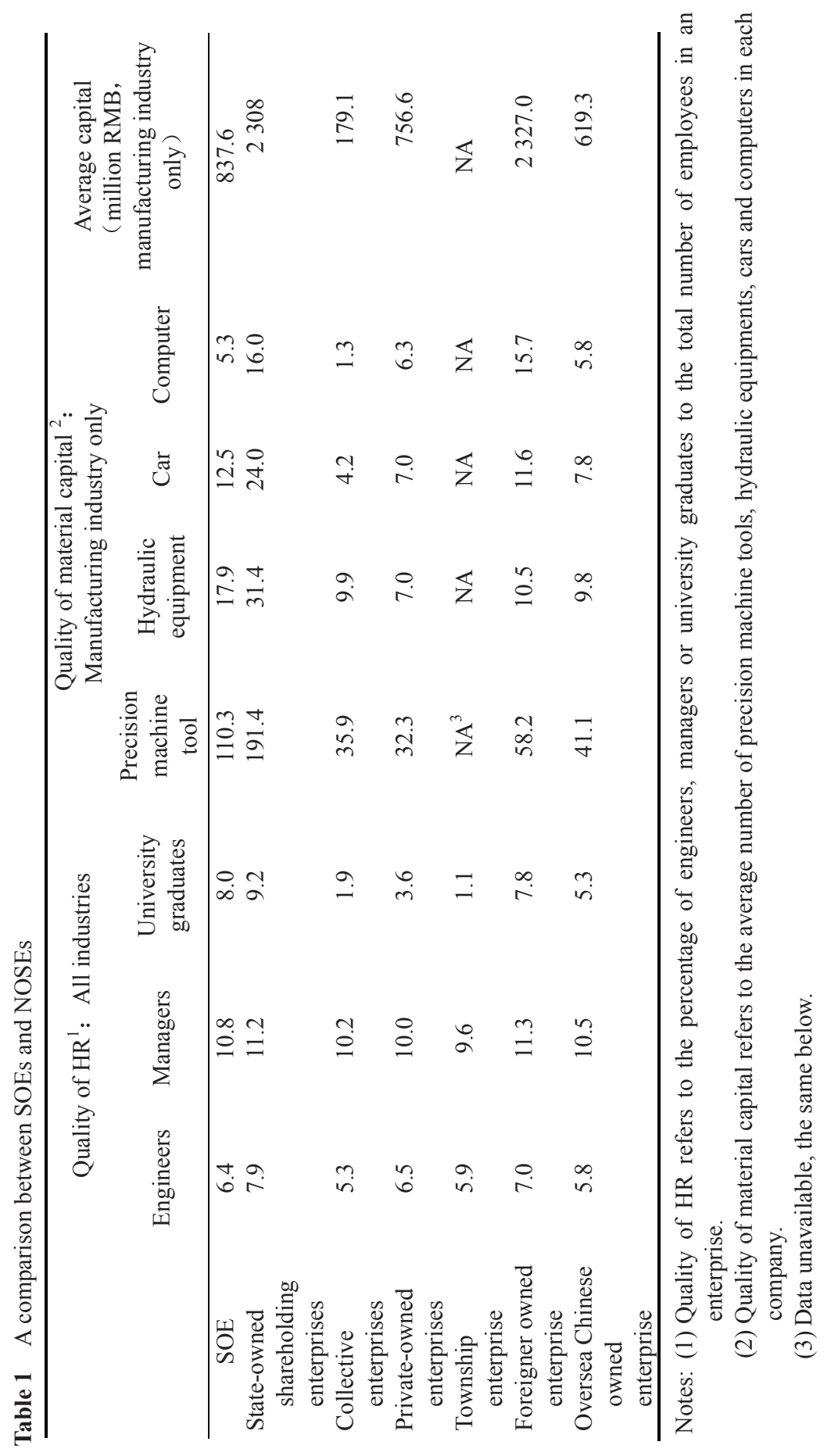


problem, the property right school proposes a solution of enhancing the supervisory function of shareholder by means of establishing proper property right mechanisms, while the Management School hopes to motivate managers through effective incentive mechanisms.

The above two schools' presumptions, however, deny differences in managers' leadership capabilities. Under the condition of limited leadership capabilities, property right mechanism or incentive mechanism can not compensate managers' bounded rationality. With a fully-developed market of professional managers, harsh external competition can eliminate those less capable managers. Thus we can ignore difference in managers' capabilities. In the Chinese context, however, professional managers from other types of enterprises hardly have any access to the top managerial positions in SOEs. Besides, managers in SOEs are assigned and supervised by the government. When deciding whether or not promote a manager, his political background and tenure at the present position are of key importance. As a result, there are huge differences in the managerial capabilities of SOE managers, which in turn cause differentiation of SOEs' enterprise performances. By far, there has been no empirical study on SOE efficiency from the perspective of leadership capability. In the present article, we attempt to fill this gap in enterprise efficiency research.

\section{Extant explanations for SOE efficiency}

\subsection{The property right school}

The property right school argues that, as owned by state and controlled by certain government departments, inefficiency is an inherent attribute of SOEs. Government departments are not ideal proprietor for they have an array of complicated goals (other than only economic goals) when running SOEs, resulting in a large amount of invalid enterprise behavior. Since government departments concerned are unable to run SOEs as efficient as private owners, the best way to reduce the control of government exerted upon SOEs is to diversify property right structure. The key of reform lies in a separation between property right and control. Privatization has been proved to be an effective approach (Shleifer and Vishny, 1994). The study of Frydman, Gray, Marek and Rapaczynski (1996) supported a positive effect of privatization on enterprise performance. Liu and Li's (2005) study showed, based on survey data of 491 Chinese enterprises, the privatization of SOEs is positively related to the improvement of enterprise efficiency. Song and Yao (2005) collected panel data of 681 enterprises and concluded that reform has positive impacts on enterprise profit margin. Li and Wu's (2001) study also found a positive and significant 
relationship between multiplication of property rights and SOE performance.

\subsection{The management school}

Contrary to the opinion that SOEs are born inefficient, the management school, originated from the decentralization theory and the principal-gent theory, believes that there are no essential differences between SOEs and NSOEs. Scholars from the school argue that the root cause of SOE inefficiency lies in government's inefficient management. Thus the key of reform is to ameliorate the enterprise management mechanisms, such as employee empowerment, profit incentive system, etc. Following the line, Groves, Hong, Mcmillan and Naughton (1994, 1995) studied the effects of operating mode reform, revealing a positive relation between autonomy, profit-sharing system and SOE performance and the managerial efficiency. Walder (1989) found that SOE leaders tend to improve employee welfare by means of setting up welfare fund, building up dormitories or other strategies. Motive behind these behaviors is management mechanism improvement. Nee (1991) pointed out that in a transition economy, SOE leaders, as government officials, gain little economic returns from enterprise performance, which partly cause the low level of enthusiasm among the SOE managers.

\subsection{The leadership capability school}

Idiosyncrasy theories focus on a leader's personality and explain his business success or failure accordingly, with Stogdill as the most prominent scholar. Studies followed the line of idiosyncrasy theory reached, however, quite inconsistent conclusions (Stoghill, 1974). Later, the contingency theory attempted to combine environment factors and personality factors together as an explanation variable of leadership effectiveness. Kahn's (1993) study on baseball teams confirmed that leadership capability exerts a considerable influence on organization performance. Lieberman, Lau and Willimas's (1990) investigation on the performance growth rates of six American and Japanese automobile manufacturers revealed that leadership capability is significantly related to enterprise performance. Hambrick and Mason (1984) proposed the "upper echelon theory" and presumed that an organization's strategy choice and level of enterprise performance rest with, to a large extant, the background and characteristics of the top managers in that organization. The education level and working experience endow these managers with specific skills and styles, as embodied in different leadership capabilities. These differences in leadership capabilities in turn exert significant influence on an enterprise's performance. Many empirical studies that followed supported the "upper echelon theory" 
(Amason, 1984; Finkelstein and Hambrick, 1984). Elron, Haleblian and Finkelstein proposed that demographic characteristics (including team members' ages, education level, major, working experiences and culture background, etc) directly or indirectly influence an enterprise's performance. They pointed out that these demographic characteristics affect a manager's view of value, cognitive frame, decision-making behavior and style, resulting in differences in managerial capabilities.

\section{Methods}

\subsection{Research framework}

Meyer (2004) found that Chinese government adopted neither shock therapy nor the commonly used gradual reform approach in her SOE reform. He described this type of reform mode as a hierarchical empowering movement, in which the central government transfer management autonomy and the decision-making authority of regional economic issues to local governments and local governments in turn empower SOEs leaders the above two rights. In practice, since there are no rigid empowerment regulations to abide by, SOEs have gained much more decision-making powers. As above, SOEs have a lot of advantages in human resources and material capital over other types of enterprises. Under such circumstances, we presumed that the leadership capability of a SOE leader becomes one of the important determinants of enterprise performance. But how can we measure leadership capability? Will the above hypothesis be supported by empirical test? Much to our dismay, Meyer did not give any answers to our questions. In the present article, we contended that leadership capability can be measured through individual dimensions of the upper echelon team.

As shown in Fig.1, our conceptual model combines opinions from the property right school versus the management school of thoughts on SOEs, and the Upper Echelon Theory together, aiming at probing into the correlation between leadership capability (as reflected by a leader's demographic characteristics) and enterprise performance. This model attributes to the existing study on SOE performance by introducing in new influencing factors, which is of inspiring significance to the improvement of SOE performance researches. 


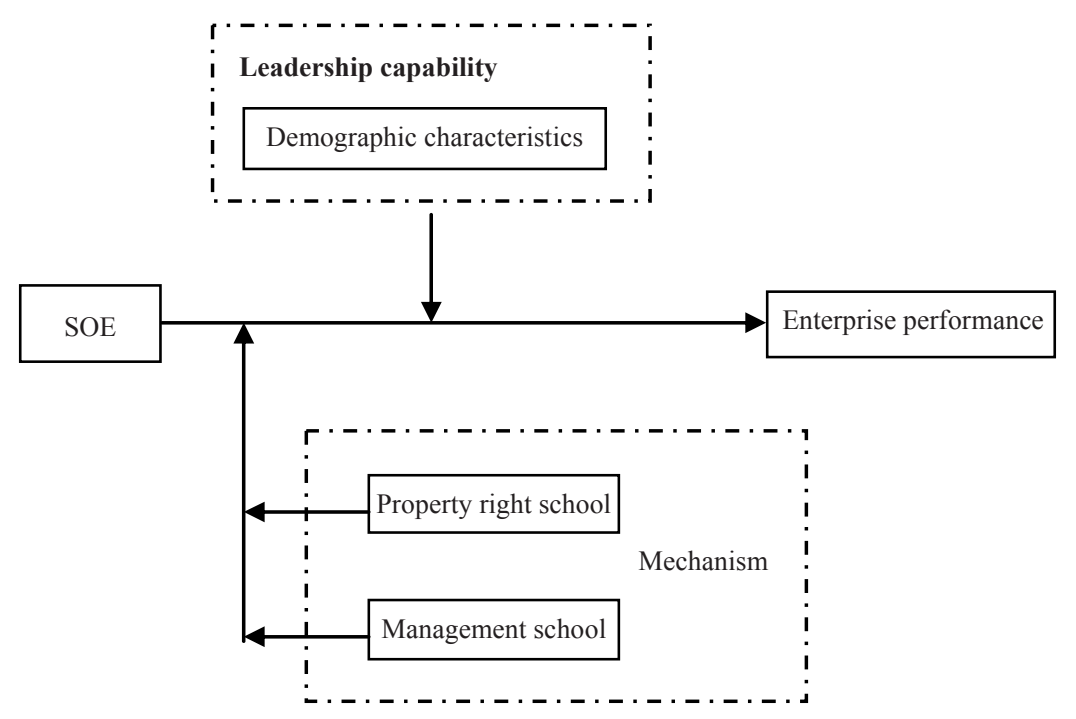

Fig. 1 The conceptual model of this study

\subsection{Hypotheses}

The management school presumes that management shareholding would alleviate, to a certain degree, the conflicts between managerial personnel and shareholders. Thus the ratio of shares held by management shall be positively related to enterprise performance(Jensen and William, 1976). However, Demsetz and Lehn's (1985) empirical study on 511 listed American companies failed to support this presumption. Yuan, Wang and Liu (2000) found no significant correlation between top management shareholding in listed companies and company performance. Wei (2000) thus argued that there is no "region effects" between management share-holding ratio and enterprise performance. Wu's (2002) study revealed that there is a significant reverse U-shaped relation between the staff share ratio and enterprise performance. Zhou and Sun (2003), however, found that for enterprises "in growth phase", management shareholding is positively related to enterprise performance. Taken together, there have been no convincing and consistent conclusions of the said problem. We thus develop the following hypothesis:

H1: Management shareholding is positively related to SOE performance.

As above, the property right school highlights a diversified property right structure. In doing so, privatization is proposed as an effective way leading to a final separation between SOE property right and control. A number of recent researches have confirmed the positive effect privatization has on SOE 
performance(Hu, Song and Zheng, 2002; Megginson, and Netter, 2001). Drawing on the above rationale, we presume that:

H2: In SOEs, the degree of multiplication of property rights(DMPR) is positively related to enterprise performance.

Generally speaking, the more diversified a SOE's property right are, the better its performance. In the present article, we adopt the proportion of non-state-owned shares in the total assets of a SOE as an index of DMPR.

Hambrick and Snow(1977) deemed that a manager's demographic characteristics as more recognizable background symbols, including age, education level, tenure, specification and working experiences, etc. They pointed out that these traits will influence managers' value orientations, cognitive perfections, personal beliefs, and attitudes towards risks, which in turn affect an organization strategy choices and performance. Specifically, a manager's education level affects his/her cognitive style, thinking mode, information-process ability and value(John and Ernes, 1986), attributing positively to an organization's performance(Hambrick and Chen, 1996). Also, a diversified and specificallyeducated management team and a management team specialized in science and engineering will have affirmative impacts on an organization's strategy change (Wicrscana and Bantel, 1992; Smith and Olian, 1996). Meanwhile, the longer a leader's tenure in a SOE, the higher stability the decision making process, the higher level of decision implementation (accompanied with weakened creative thinking and rigidified thinking framework)(Hambrick and Fukutomi, 1991). Finally, leaders with oversea experiences tend to have wider and more internationalized views, contributing to higher quality enterprise decisions. Due to data limitation, we focus in the present article only the effects of SOE leaders' education level, tenure and oversea experiences on enterprise performance. Accordingly, we propos hypotheses as below:

H3a: The higher education level of a SOE leader, the better the enterprise performance.

H3b: The longer tenure of a SOE leader, the better the enterprise performance.

H3c: SOE leaders with oversea experiences tend to achieve better performances than that of SOE leaders without.

We argue that NSOEs (including private-owned enterprises, foreign invested companies, domestic stock companies, collective companies) have more reasonable ownership structure and more efficient management mechanisms than that of SOEs. Thus we assumed that leadership capabilities have less significant impact on enterprise performance in NSOEs than that of in SOEs. We thus develop the corresponding hypothesis as below:

H3d: The effects of a leader's demographic characteristics (namely, education level, tenure and oversea experience) on enterprise performance are higher in SOEs than that of in NSOEs. 
Drawing on Meyer's (2004) conclusions, we inferred that leadership capability must have a significant impact on enterprise performance since the said SOE empowering reform does not have compulsory and standardized guidelines to follow. Hence diversified leadership capabilities will lead to diversified SOE performance.

H4: DMPR in SOEs is higher than that of in NSOEs, due to the impact of SOE empowering reform.

\subsection{Data source}

Considering that the collection of SOE managers' personal information and enterprise financial statistics is quite difficult, we use in the present article survey data of the World Bank on 1500 enterprises from 5 Chinese cities in 2001. As depicted in Table 2, the sampled cities were Beijing, Chengdu, Guangzhou, Shanghai and Tianjin and surveyed enterprises distributed more or less evenly in 10 industries, namely clothes and leather product making, household supplies manufacturing, electronic components manufacturing, electronic equipment manufacturing, automobile and parts manufacturing, auditing services, advertising and marketing service, business logistics, telecommunication and IT services. Most of these industries have the greatest potential competitiveness in Chinese market.

Table 2 Distribution of sampled cities and industries

\begin{tabular}{lcccccr}
\hline & Beijing & Chengdu & Guangzhou & Shanghai & Tianjin & Total \\
\hline Auditing services & 23 & 20 & 18 & 20 & 23 & 104 \\
$\begin{array}{c}\text { Advertising and } \\
\text { marketing services }\end{array}$ & 20 & 19 & 11 & 20 & 19 & 89 \\
$\begin{array}{c}\text { Clothes and leather } \\
\text { product making }\end{array}$ & 49 & 45 & 46 & 40 & 42 & 222 \\
$\begin{array}{c}\text { Business logistics } \\
\text { Telecommunication }\end{array}$ & 23 & 20 & 29 & 20 & 18 & 110 \\
$\begin{array}{c}\text { Household supplies } \\
\text { manufacturing }\end{array}$ & 11 & 17 & 12 & 20 & 11 & 71 \\
$\begin{array}{c}\text { Electronic components } \\
\text { manufacturing }\end{array}$ & 43 & 40 & 33 & 40 & 35 & 165 \\
$\begin{array}{c}\text { Electronic equipment } \\
\text { manufacturing }\end{array}$ & 41 & 35 & 40 & 40 & 36 & 192 \\
$\begin{array}{l}\text { IT services } \\
\text { Automobile \& parts }\end{array} \quad 25$ & 24 & 30 & 20 & 29 & 128 \\
$\quad$ manufacturing & 44 & 24 & 42 & 40 & 46 & 216 \\
Total & 300 & 300 & 300 & 300 & 300 & 1500 \\
\hline
\end{tabular}


Questionnaires were composed of two parts: Part one was basic information entries, such as ownership structure, tax, cost, and labor forces, etc., which were filled in by the financial personnel in the enterprise. Part Two consisted of entries such as enterprise competitiveness, innovation and internal \& external relationship (namely, the enterprise's relation with its customers, suppliers, government departments concerned and research centers). Questions in Part Two were completed by conducting fact-to-face interviews with top managers. The financial data collected ranged from 1998 to 2000 and interview data was mainly based on 2000 .

\subsection{Variables}

\subsubsection{Dependent variables}

Enterprise performance was used as dependent variable. Venkatraman and Ramanujam(1986) pointed out that the ultimate purpose of each activity in an enterprise is for performance improvement. Scholars have adopted an array of different methods and theoretical models to measure enterprise performance. Compell (1977), in an organizational efficacy literature review, summarized 30 organization performance-measuring indexes, consisting of five categories: (1) productivity, as measured by means of production; (2) performance, as co-evaluated by employees and managers; (3) employee satisfaction, as measured by questionnaires; (4) employee turnover rate, as measured by personnel records; (5) rate of profit or return on investment, as measure by financial reports. Ruekert, Walker and Roering (1985) categorized organizational performance into three dimensions, namely efficiency (as represented by returns on investment), effectiveness (referring to sales growth rate and market share), and adaptability (referring to an enterprise's environment-adaptive ability). Nkomo (1987) laid emphases on the evaluations of financial performance and HR performance. The former includes returns on investment, surplus growth rate, etc; the latter consists of employee evaluation and income, average production quote per person, etc.

Since SOEs pursue a wide range of goals other than mere economic returns, which is quite different from the profit-maximization-seeking modern enterprises in mature market economy. Based on the above hypotheses, we choose gross rate of return on assets (GROR) as a major index of enterprise performance measurement. GROR equals an enterprise's total assets divided by earnings before tax. Theoretically, GROR is more precise than accounting profit ration for bonus granted to employees will affect the latter. 


\subsubsection{Independent variables}

We used the ratio of shares held by management, the degree of ownership diversification, and leaders' demographic characteristics (namely education level, tenure and oversee experiences) as independent variables.

\subsubsection{Ratio of shares held by management}

Commonly adopted incentive mechanisms are benefit-oriented, promotion-oriented or honor-oriented. Among these mechanisms, benefit-oriented incentive mechanism lies in the core of management stimulation. Hence we used the ratio of shares held by management as a major index of incentive mechanism measurement, as obtained directly from the World Bank's 2001 survey.

\subsubsection{The degree of multiplication of property rights(DMPR)}

DMPR is measured by the ratio of non-state-owned shares in the total assets of SOEs. The index of DMPR is the ratio of non-state-owned shares divided by the total assets of a SOE, with a value range of 0 to 1 .

\subsubsection{Leaders' demographic characteristics}

We chose only three dimensions of a leader's demographic characteristics, namely education level, tenure and oversea experiences. The educational level is divided into six sub-levels: master degree (both from foreign and domestic universities) or above, bachelor degree (both from foreign and domestic universities) or above, senior high school, junior high school, primary school and illiterate, as represented by numbers 6 to 1 respectively. Tenure refers to the years a leader holds the present position since 2000 (calculated directed from the survey data). As for the dimension of oversea experiences, if a SOE leader did not have any oversea study experiences and he/she has Chinese nationality, we regarded he/she as having no oversea experience. If the leader meets either of the above two requirements (or both requirements), we regarded he/she as having oversea experiences. The dimension of oversea experiences was represented by a dummy variable, with 1 standing for having oversea experiences and 0 otherwise.

\subsubsection{Control variables}

The control variables used in the present article include enterprise size, nature of the enterprise, industry attributes and enterprise age. 


\subsubsection{Enterprise size}

An Enterprise's size is an important determinant of its performance(Weiner, 1981; Wernerfelt and Montgomery, 1988). The bigger an enterprise, the more assets it has or controls, the more obvious the scale economies effects and reputation effects, hence the better the financial performance(Lee and Pennings, 2001; King and Zeithaml, 2001). We used the logarithm of an enterprise's total assets as an index of enterprise size variable to avoid possible differences in magnitude among variables.

\subsubsection{Enterprise nature}

Enterprise nature has long been regarded as one of the influencing factors of enterprise performance. In the present article, we categorized the enterprises surveyed, in accordance with the survey data, into five sub-groups, namely, SOEs, private-owned enterprises, foreign-invested enterprises, domestic stock companies, and collective enterprises.

\subsubsection{Industrial attributes}

Industrial economics has pointed out that characteristics of industrial structure are major determinants of enterprise performance(Porter, 1997). The Structure-Conduct-Performance Model is a widely used theoretical framework of analyzing the relation between industrial structure and profit margin. Since profit margins vary with different industries, industrial attributes exert impacts on enterprise performance. Drawing on existing industry category standards, we classified clothes and leather product making, household supplies manufacturing, automobile \& parts manufacturing as non-high-tech manufacturing industries; electronic components manufacturing, electronic equipment manufacturing as high-tech manufacturing industries; auditing services, advertising and marketing service, business logistics as non-high-tech service industries and telecommunication and IT services as high-tech service industry. Dummy variable is set up to differentiate influences from industrial attributes on enterprise performance: it equals 1 when belongs to certain industry and 0 otherwise.

\subsubsection{Enterprise age}

Newly established enterprises face "newcomer's risk". As an enterprise's knowledge and capability grow with time passes by, enterprise age affects enterprise performance. In the present article, enterprise age refers to years from 
an enterprise's establishment to 2000.

\subsubsection{Regression model}

We use regression model to describe the relationships between DMPR and enterprise performance, leaders' demographic characteristics and enterprise performance respectively. Below is regression model of the relation between $D M P R$ and $\operatorname{GROR}\left(Y_{i t}\right)$.

$$
Y_{i t}=\alpha_{0}+\alpha_{0} O_{i t}+\alpha_{1} \log \left(K_{i t}\right)+\alpha_{2} N_{i t}+\alpha_{3} Z_{i t}+\varepsilon_{i t}
$$

Among the parameters, $Y_{i t}, O_{i t}, K_{i t}, N_{i t}$, and $Z_{i t}$ represent the performance level, $D M P R$, total assets, enterprise age, and enterprise nature of enterprise $i$ at time $t$ respectively. $\varepsilon_{i t}$ is random error.

Next is the model of the relation between leaders' demographic characteristics, namely education level $\left(E_{i t}\right)$, tenure $\left(T_{i t}\right)$ and oversea experiences $\left(W_{i t}\right)$ and $\operatorname{GROR}\left(Y_{i t}\right)$.

$$
Y_{i t}=\beta_{0}+\beta_{e} E_{i t}+\beta_{t} T_{i t}+\beta_{w} W_{i t}+\beta_{1} \log \left(K_{i t}\right)+\beta_{2} N_{i t}+\beta_{3} Z_{i t}+\eta_{i t}
$$

Among the parameters, $Y_{i t}, E_{i t} T_{i t}$, and $W_{i t}$ represent the performance level, leader's education level, leader's tenure, leader's oversea experiences of enterprise $i$ at time $t$ respectively. $\eta_{i t}$ is random error. The definitions of $K_{i t}, N_{i t}$, and $Z_{i t}$ are the same as in Model (1).

Data were analyzed using SPSS for Windows 13.0.

\section{Results}

Comparisons of performance variances among different types of enterprises are depicted in Table 3, which shows that standard variances of SOEs' GROR are 64.29 in 1998, 16.14 in 1999, and16.62 in 2000 respectively, distinctly higher than other types of enterprises, especially in the year of 1998.

Table 3 Comparisons of performance variances among different types of enterprises

\begin{tabular}{lccrr}
\hline \multirow{2}{*}{ enterprise nature } & Number of & \multicolumn{3}{c}{ Standard errors of GROR } \\
& samples & 2000 & 1999 & 1998 \\
\hline SOE & 308 & 16.62 & 16.14 & 64.29 \\
Private-owned enterprises & 178 & 6.92 & 7.34 & 8.11 \\
Foreign-invested & 187 & 2.89 & 2.26 & 8.18 \\
$\quad$ enterprises & 217 & 5.53 & 6.01 & 5.32 \\
Domestic stock companies & 218 & 11.02 & 8.55 & 13.41 \\
Collective enterprises & 1,108 & 10.79 & 10.20 & 34.81 \\
Total & & & & \\
\hline
\end{tabular}


Thus $\mathrm{H} 4$ is supported: empowering reforms in SOEs have given rise to different levels of enterprise performances.

As shown in Table 4, the concomitant possibilities of $F$ in 1998, 1999, and 2000 are $0.511,0.680$, and 0.532 , respectively. Hence the hypothesis of equal variance can not be rejected. When variances equal, the concomitant possibilities of $t$-statistic are $0.858,0.654$ and 0.728 , respectively. Hence the null hypothesis of $T$-test can not be rejected. In other words, there are no significant differences between the GRORs of enterprises with incentive mechanisms and those without. Hence $\mathrm{H} 1$ is not supported.

Table $4 T$-test of the relation between incentive mechanism and enterprise performance

\begin{tabular}{|c|c|c|c|c|c|c|}
\hline \multirow{2}{*}{ GROR } & \multirow{2}{*}{ Variances } & \multicolumn{2}{|c|}{$\begin{array}{l}\text { Levene test for } \\
\text { equality of variances }\end{array}$} & \multicolumn{3}{|c|}{$T$-test for equality of variances } \\
\hline & & $F$ test & Significance & $t$ & $\begin{array}{l}\text { Degree of } \\
\text { freedom }\end{array}$ & $\begin{array}{l}\text { Significance } \\
(\text { two-tailed })\end{array}$ \\
\hline Year & $\begin{array}{l}\text { Equal variances } \\
\text { assumed }\end{array}$ & 0.391 & 0.532 & 0.179 & 1,488 & 0.858 \\
\hline 2000 & $\begin{array}{l}\text { Equal variances } \\
\text { not assumed }\end{array}$ & & & 0.705 & 1,441 & 0.481 \\
\hline Year & $\begin{array}{l}\text { Equal variances } \\
\text { assumed }\end{array}$ & 0.170 & 0.680 & -0.448 & 1,399 & 0.654 \\
\hline 1999 & $\begin{array}{l}\text { Suppose variances } \\
\text { not equal }\end{array}$ & & & -0.768 & 107.5 & 0.444 \\
\hline Year & $\begin{array}{l}\text { Equal variances } \\
\text { assumed }\end{array}$ & 0.431 & 0.511 & 0.348 & 1,298 & 0.728 \\
\hline 1998 & $\begin{array}{l}\text { Suppose variances } \\
\text { not equal }\end{array}$ & & & 1.179 & 425.5 & 0.239 \\
\hline
\end{tabular}

Table 5 shows that there is a significant positive relation between DMPR and enterprise performance. Therefore, $\mathrm{H} 2$ is supported.

Table 5 Correlation analysis of $D M P R$ and enterprise performance

\begin{tabular}{ccccc}
\hline & GROR in 2000 & GROR in 1999 & GROR in 1998 \\
\hline$D M P R$ & $\begin{array}{c}\text { Pearsonion } \\
\text { correlation } \\
\text { coefficient }\end{array}$ & $0.415^{* *}$ & $0.203^{*}$ & $0.409^{* *}$ \\
& & & 0.024 & 0.000 \\
Significance(two-tailed) & 0.000 & 124 & 116 \\
\hline Total samples & 126 & &
\end{tabular}

Notes: $* * p=0.01, * p=0.05$. 
To further explore how $D M P R$ affects performance, the authors conducted a total regression analysis, choosing the most representative GROR in 2000, as demonstrated in Table 6.

Table 6 General description of the above two regression models

\begin{tabular}{ccccccccc}
\hline Models & $R$ & $R^{2}$ & $R^{2}$ adjusted & $\begin{array}{c}\text { Amount of } \\
\text { changes in } \\
R^{2}\end{array}$ & $\begin{array}{c}\text { Changes } \\
\text { in } F\end{array}$ & $\begin{array}{c}\text { Numerator in statistics } \\
\text { degree of } \\
\text { freedom }\end{array}$ & $\begin{array}{c}\text { Cominator } \\
\text { degree of } \\
\text { freedom }\end{array}$ & $\begin{array}{c}\text { Changes in } \\
\text { significance } \\
\end{array}$ \\
& & & & & & & & \\
\hline $1^{\text {a }}$ & 0.392 & 0.154 & 0.118 & 0.154 & 4.357 & 5 & 120 & 0.001 \\
$2^{\mathrm{b}}$ & 0.559 & 0.312 & 0.278 & 0.159 & 27.441 & 1 & 119 & 0.000 \\
\hline
\end{tabular}

Notes:

(1) independent variables: (constant), hi-tech service industries, hi-tech manufacturing, traditional manufacturing, log of total assets, enterprise age.

(2) independent variables: (constant), hi-tech service, hi-tech manufacturing, traditional manufacturing, log of total assets, enterprise age, $D M P R$.

(3) dependent variable: GROR in 2000.

As depicted, $R$ of Model (1) is 0.393 and adjusted $R^{2} 0.118$, indicating that there is only an average correlation between independent variables and dependent variable. In other words, at the significant level of $p<0.01$, about $11.8 \%$ of $G R O R$ variance can be explained by independent variables. By comparison, $R$ of Model (2) is 0.559 and adjusted $R^{2} 0.118$ (the amount of changes in $R^{2}$ is 0.159 ), implying that the correlation in the second model is significantly higher than that of in Model (1). In other words, DMPR has a significant impact on GROR. By adopting the total regression method, we get a new linear regression equation as below:

$$
\begin{aligned}
G R O R= & 13.117^{* *+}+0.226^{* *} \times D M P R-3.631 * * \times \text { total assets log } \\
& +0.101 \times \text { enterprise age }-1.922 \times \text { hi-tech manufacturing } \\
& +7.863^{*} \times \text { high-tech service }-1.708 \times \text { traditional service }
\end{aligned}
$$

The equation shows that when DMPR increases 1, GROR adds 0.226 , a result consistent with the property right school's opinions - a diversified property right structure can enhance an enterprise's performance.

Next, we are going to test the effect of leader's demographic characteristics on enterprise performance. We divide sampled enterprises into two sub-groups of SOEs and NSOEs (including private-owned enterprises, foreign-invested enterprises, domestic stock companies, and collective enterprises) and conducted regression analyses of both groups respectively. 
Table 7 General description of the above two regression models (SOEs)

\begin{tabular}{|c|c|c|c|c|c|c|c|c|}
\hline \multirow[b]{2}{*}{ Models } & \multirow[b]{2}{*}{$R$} & \multirow[b]{2}{*}{$R^{2}$} & \multirow[b]{2}{*}{$R^{2}$ adjusted } & \multicolumn{5}{|c|}{ Changes in statistics } \\
\hline & & & & $\begin{array}{c}\text { Amount of } \\
\text { changes in } \\
R^{2}\end{array}$ & $\begin{array}{l}\text { Changes } \\
\text { in } F\end{array}$ & $\begin{array}{l}\text { Numerator } \\
\text { degree of } \\
\text { freedom }\end{array}$ & $\begin{array}{l}\text { Denominator } \\
\text { degree of } \\
\text { freedom }\end{array}$ & $\begin{array}{c}\text { Changes in } \\
\text { significance } \\
F\end{array}$ \\
\hline 1 & 0.283 & 0.080 & 0.065 & 0.080 & 5.462 & 5 & 315 & 0.077 \\
\hline 2 & 0.316 & 0.100 & 0.077 & 0.020 & 2.301 & 3 & 312 & 0.000 \\
\hline
\end{tabular}

Notes:

(1) Independent variables: (constant), enterprise age, log of total assets, hi-tech manufacturing, hi-tech service, traditional service.

(2) Independent variables: (constant), enterprise age, log of total assets, hi-tech manufacturing, hi-tech service, traditional service, oversea experiences, tenure, education level.

(3) Dependent variable: GROR in 2000.

(4) Samples include SOEs only.

The explanation power in Model (2), as revealed in Table 7, increases by $2 \%$, showing that SOE leaders' demographic characteristics affect GROR. Table 8 shows that among the three chosen demographic characteristics, only the characteristic of education level influence significantly enterprise performance. Further analysis indicates that although oversea experience is not significantly related to an enterprise's overall performance, it affects the enterprise's international strategy. Leaders with oversea experiences are more inclined to adopt import \& export strategies. Besides, the oversea market shares in their enterprises are markedly higher than that of enterprises without oversea experienced leaders. Similarly, foreign-invested companies also exert positive influences on local economies through this type of knowledge spillover effect (Long and Hale, 2006).

Table 8 Coefficients analysis table (SOEs)

\begin{tabular}{|c|c|c|c|c|c|c|}
\hline \multirow{2}{*}{\multicolumn{2}{|c|}{ Models }} & \multicolumn{2}{|c|}{$\begin{array}{l}\text { Un-standardized } \\
\text { coefficients }\end{array}$} & \multirow{2}{*}{$\begin{array}{c}\text { Standardized } \\
\text { coefficients } \\
\text { Beta } \\
\text { distribution } \\
\end{array}$} & \multirow{2}{*}{$t$} & \multirow{2}{*}{ Significance } \\
\hline & & $\begin{array}{l}\text { Estimated } \\
\text { value of B }\end{array}$ & $\begin{array}{c}\text { Standard } \\
\text { error }\end{array}$ & & & \\
\hline \multirow{6}{*}{1} & (Constants) & 17.992 & 4.046 & & 4.446 & 0.000 \\
\hline & Total assets log & -4.222 & 0.920 & -0.275 & -4.591 & 0.000 \\
\hline & $\begin{array}{l}\text { Hi-tech } \\
\text { manufacturing }\end{array}$ & 3.364 & 2.346 & 0.088 & 1.434 & 0.153 \\
\hline & Hi-tech service & 4.237 & 3.074 & 0.088 & 1.378 & 0.169 \\
\hline & $\begin{array}{l}\text { Traditional } \\
\text { service }\end{array}$ & 0.543 & 2.359 & 0.015 & 0.230 & 0.818 \\
\hline & Enterprise age & 0.019 & 0.051 & 0.024 & 0.380 & 0.704 \\
\hline
\end{tabular}

(To be Continued) 


\begin{tabular}{|c|c|c|c|c|c|c|}
\hline \multirow{2}{*}{\multicolumn{2}{|c|}{ Models }} & \multicolumn{2}{|c|}{$\begin{array}{l}\text { Un-standardized } \\
\text { coefficients }\end{array}$} & \multirow{2}{*}{$\begin{array}{c}\text { Standardized } \\
\text { coefficients } \\
\text { Beta } \\
\text { distribution } \\
\end{array}$} & \multirow{2}{*}{$t$} & \multirow{2}{*}{ Significance } \\
\hline & & $\begin{array}{l}\text { Estimated } \\
\text { value of B }\end{array}$ & $\begin{array}{c}\text { Standard } \\
\text { error }\end{array}$ & & & \\
\hline \multirow{9}{*}{2} & (constant) & 3.191 & 7.573 & & 0.421 & 0.674 \\
\hline & Total assets log & -4.947 & 0.957 & -0.322 & -5.168 & 0.000 \\
\hline & $\begin{array}{l}\text { Hi-tech } \\
\text { manufacturing }\end{array}$ & 2.677 & 2.348 & 0.070 & 1.140 & 0.255 \\
\hline & Hi-tech service & 3.531 & 3.095 & 0.073 & 1.141 & 0.255 \\
\hline & $\begin{array}{l}\text { Traditional } \\
\text { service }\end{array}$ & 0.058 & 2.361 & 0.002 & 0.025 & 0.980 \\
\hline & Enterprise age & 0.042 & 0.051 & 0.053 & 0.825 & 0.410 \\
\hline & Education level & 4.535 & 1.799 & 0.145 & 2.521 & 0.011 \\
\hline & Tenure & -0.087 & 0.215 & -0.022 & -0.405 & 0.686 \\
\hline & $\begin{array}{l}\text { Oversea } \\
\text { experiences }\end{array}$ & -5.934 & 7.174 & -0.045 & -0.827 & 0.409 \\
\hline
\end{tabular}

Notes:

(1) Dependent variable: GROR in 2000.

(2) Samples include SOEs only.

Hence, by adopting the full regression method, we got a linear regression equation for GROR as below:

$$
\begin{aligned}
G R O R= & 3.191-4.947 * * \times \text { total asset } \log +4.535 * \times \text { education level } \\
& +2.677 \times \text { hi-tech manufacturing }+3.531 \times \text { hi-tech service } \\
& +0.058 \times \text { traditional service }+0.042 \times \text { enterprise age }
\end{aligned}
$$

As shown in Table 9, we find leaders' demographic characteristics are not significantly related to enterprise performance in NSOEs. Possible explanation is that property right structure and incentive mechanisms in NSOEs are comparatively more reasonable, thus leadership capabilities have less decisive impact on enterprise performance than that of in SOEs. Hypotheses 3a and $3 \mathrm{~d}$ are supported. Specifically, SOE leaders' education level is significantly positively related to enterprise performance and their demographic characteristics affect enterprise performance more significantly than that of in NSOEs.

\section{Conclusions}

SOE reforms are of key importance to China's economic transition. The vast majority of extant researches on SOE reforms, however, have focused on relevant mechanisms. Studies concentrating on SOE leaders are still lacking. In 
the present article, we attempt to explore the relationship between SOE leaders' demographic characteristics and enterprise performance, as well as to test the viewpoints of the property right school versus the management school.

Table 9 General description of the above two regression models (NSOEs)

\begin{tabular}{ccccccccc}
\hline Models & $R$ & $R^{2}$ & $\begin{array}{c}R^{2} \\
\text { adjusted }\end{array}$ & \multicolumn{2}{c}{$\begin{array}{c}\text { Amount of } \\
\text { changes in }\end{array}$} & \multicolumn{4}{c}{$\begin{array}{c}\text { Changes in statistics } \\
\text { in } F\end{array}$} \\
& & & & $R^{2}$ & $\begin{array}{c}\text { Numerator } \\
\text { degree of } \\
\text { freedom }\end{array}$ & $\begin{array}{c}\text { Denominator } \\
\text { degree of } \\
\text { freedom }\end{array}$ & $\begin{array}{c}\text { Changes in } \\
\text { significance } F\end{array}$ \\
\hline 1 & 0.071 & 0.005 & 0.001 & 0.005 & 1.230 & 5 & 1,159 & 0.292 \\
2 & 0.077 & 0.006 & -0.001 & 0.000 & 0.114 & 3 & 1,156 & 0.952 \\
\hline
\end{tabular}

Notes:

(1) Independent variables: (constant), enterprise age, log of total assets, hi-tech manufacturing, hi-tech service, traditional service.

(2) Independent variables: (constant), enterprise age, log of total assets, hi-tech manufacturing, hi-tech service, traditional service, oversea experiences, tenure, education level

(3) Dependent variable: GROR in 2000

(4) Samples include NSOEs only.

To ensure the authenticity and integrality of data used, we use the survey data of the World Bank in 2001. We presume those enterprise leaders' demographic characteristics, property right structure, and incentive mechanisms all exert effects on enterprise performance and establish a conceptual model of leadership capability accordingly. When testing the model, we control the influences from enterprise nature, enterprise size, industrial attributes, and enterprise age.

Our conclusions confirm the property right school's viewpoint that multiplication of property right can significantly enhance enterprise performance. But perspectives from the management school are not supported. Our study also proves that leader's demographic characteristics affect enterprise performance. By comparison, SOEs have less reasonable property right structure and less efficient incentive mechanisms, thus leaders' demographic characteristics have greater impact on enterprise performance in SOEs than that of in NSOEs (private-owned enterprises, foreign-invested enterprises, domestic stock companies, and collective enterprises).

Why incentive policies have not worked as planned? Theoretically, good incentive policies should stimulate managers, as well as exert certain constraints over them. In practice, however, several factors have kept these incentive mechanisms from taking effects: first, the proportion of shares held by top managers is too small to stimulate them effectively; second, the manager-share-holding system has degenerated into a kind of "welfare" thanks to the huge price difference between China's primary stock market and secondary market, as long as managerial personnel hold a company's stocks, they will gain 
fat profit almost automatically. Once a share-holding incentive mechanism becomes part of welfare system, it stops affecting enterprise performance positively.

We believe, with good reasons, that there is a huge difference in leadership capabilities in SOE leaders. For one thing, during the process of the reform of "separation of SOEs from direct governmental control", many SOE leaders come from various government departments. Some of them may not have the necessary business management qualifications or skills. For another, when selecting SOE leaders, political background has been overemphasized. In addition, reserve talents market for SOE is relatively independent and limited. Since there are different administrative ranks for China's SOEs (such as central enterprises, province-owned enterprises, city-owned enterprise, or county-owned enterprise), managerial talents from other types of enterprises can hardly have any access to managerial positions in SOEs, resulting in a contingency of SOE leaders' managerial capabilities.

The present article supports Meyer's viewpoints that the empowering reform in China's SOEs leads to differences in enterprise performance. Thus relevant studies conducted by Meyer are of guidance significance to China's SOE reforms.

This research has also some limitations. First, all sampled enterprises were from developed cities such as Beijing, Tianjin, Shanghai, Guangzhou, and Chengdu, thus the validity of our conclusions might be influenced. Second, owing to data limitation, we include in the present article only three demographic characteristics, namely education level, tenure, and oversea experiences, which is not able to reflect completely a leader's characteristics. A more accurate study should address these problems in the future.

Acknowledgements This work is supported by the National Science Foundation of China (Grant No. 70372032), the Program for New Century Excellent Talents in University from the Ministry of Education of China (Grant No. NCET-06-0804), and by the Innovation Team Training Program of the University of Electronic Science and Technology of China.

\section{References}

Amason A C(1984). Distinguishing the effects of functional and dysfunctional conflict on strategic decision making: Resolving a paradox for top management teams. Academy of Management Journal, (9): 3-148

Compell J P(1977). On The Nature Of Organizational Effectiveness. New perspectives on Organizational Effectivenes: 13-25

Demsetz H K L(1985). The structure of corporate ownership: Causes and consequences. Journal of Political Economy, (93): 1155-1177

Elron E, Haleblian J, Finkelstein S(1997). Top management teams within multinational 
corporations: Effects of cultural heterogeneity. Leadership Quarterly, (8): 393-412

Finkelstein S, Hambrick D C(1984). Strategic Leadership: Top Executives and Their Effects on Organizations. St. Paul, MN: West Publishing, 145-157

Frydman R, Cheryl G, Marek H, Rapaczynski A(1999). When does privatization work? The impact of private ownership on corporate performance in the transition economies. Quarterly Journal of economics, (114) : 1153-1191

Groves T, Hong Y, McMillan J, Naughton B(1994). Autonomy and incentives in Chinese state enterprises. Quarterly Journal of Economics, 109: 183-209

Groves T, Hong Y, McMillan J, Naughton B(1995). China's evolving managerial labor market. Journal of Political Economy, 103: 873-892

Hambrick D C, Cho T S, Chen M(1996). The influence of top management team heterogeneity on firms' competitive moves. Administrative Science Quarterly, 41: 659-684

Hambrick D C, Fukutomi G D S(1991). The seasons of a CEO's tenure. The Academy of Management Review, (16): 719-742

Hambrick D C, Mason P A(1984). Upper echelons: Top organization as a reflection of its top managers. Academy of Management Review, (9): 193-206

Hambrick D C, Snow C C(1977). A contextual model of strategic decision making in organizations. Academy of Management Proceedings, 109-112

Hu Yifan, Song Min, Zheng Hongliang(2002). The impact of ownership structural reform on the performance of China's enterprises. In: Djankov, Simeon, M.Peter, (eds.), Enterprise restructuring: a quantitative survey. Journal of Economic Literature, (40): 739-792

Huang Y(2003). Selling China: Foreign Direct Investment During the Reform Era. Cambridge: Cambridge University Press

Jefferson G H, Rawski T, Zheng Y(1999). Automation and reform in China's industrial enterprises. In: Enterprise Reform in China: Ownership, Transition, and Performance. New York: Oxford University Press

Jensen M. C, William H M(1976). Theory of the firm: Managerial behavior agency costs and ownership structure. Journal of Financial Economics, (3): 305-360

Kahn L M(1993). Managerial quality, team success, and individual player performance in major league baseball. Industrial and Labor Relations Review, (46): 531-548

King A W, Zeithaml C P(2001). Competencies and firm performance: Examining the causal ambiguity paradox. Strategic Management Journal, (22): 75-99

Lee C, Lee K, Pennings J M(2001). Internal capabilities, external networks, and performance: A study on technology-based ventures. Strategic Management Journal, (22): 615-640

Li Daokui, Wu Changqi(2004). SOE reform: Ownership diversification or management improvement? In: Anne S Tsui, Chung-Ming Lau(eds.), The management of enterprises in the P.R.C. Beijing: Peking University Press: 75-94(in Chinese)

Lieberman M B, Lao L J, Williams M D(1990). Firm-level productivity and management influence: A comparison of U.S. and Japanese automobile producers. Management Science, (6): 1193-1216

Liu Xiaoxuan, Li Liying(2005). An analysis on enterprise ownership reformation: From the perspective of efficiency. Social Sciences in China, (2): 4-16(in Chinese)

Long C X, Hale G(2006). Do FDI Inflows Increase Productivity? The Case of China. Working Paper Presented on the AEA Annual Meeting

Marshall W M, Lü Yuan, Lan Hailin, Lü Xiaohui(2004). Empowering reform in enterprises: Viewpoints on SOE reforms. In: Anne S. Tsui, Chung-Ming Lau. (eds), The Management of Enterprises in the P. R. C. Beijing: Peking University Press, 219-247(in Chinese)

Megginson W L, Jeffry M N(2001). From state to market: A survey of empirical studies on 
privatization. Journal of Economic Literature, 39: 321-189

Nee V(1991). Social inequalities in reforming state socialism: Between redistribution and markets in China. American Sociological Review, (56): 267-282

Nkomo S M(1987). Human resource planning and organization performance: An exploratory analysis. Strategic Management Journal, (8): 387-392

Porter M E(1997). Competitive Strategy. Beijing: Huaxia Press(Trans. by Chen Xiaoyue)

Ruekert R W, Walker O C, Roering K J(1985). The organization of marketing activities: Contingency theory of structure and performance. Journal of Marketing, (49):13-25

Shleifer A, Vishny R(1994). Politicians and firms. Quarterly Journal of Economics, (109): 995-1025

Smart J C, Ernes L T(1986). Self-concept development and educational degree attainment. Higher Education, (15): 3-15

Smith K G, Smith K A, Olian J D(1996). Top management team demography and process: The role of social integration and communication. Administrative Science Quarterly, 41: $658-684$

Song Ligang, Yao Yang (2005). Impacts of restructuring on firm performance in China. Social Sciences in China, (2): 17-31(in Chinese)

Stoghill R M(1974). Handbook of Leadership: A Survey of the Literature, New York: Free Press: $13-216$

Venkatraman N, Ramanujam V(1986). Measurement of business performance in strategy research: A comparison of approaches. Academy of Management, 71-78

Walder A G(1989). Factory and manager in an era of reform. China Quarterly, (118): 242-264

Wei Gang(2000). Incentives for top-management and performance of listed companies. Economic Research Journal, (3) (in Chinese)

Weiner M(1981). A model of corporate performance as a function of environmental, organizational and leadership influences. Academy of Management Journal, (24): 453-470

Wernerfelt B, Montgomery C A(1988). Tobin's $Q$ and the importance of focus in firm performance. American Economic Review, (78): 246-251

Wicrscana M F, Bantel K A(1992). Top management team demography and corporate strategic change. Academy of Management Journal, 35: 91-121

Wu ShuKun (2002). Ownership structure and firm performance: An empirical research on Chinese public companies. China Industrial Economy, (1) (in Chinese)

Yuan Guoliang, Wang Huaifang, Liu Ming (2000). An empirical study on the stock incentive mechanisms of Chinese listed companies and other problems. In: Liu Shucheng, Shen Pei (eds), A collection of frontier theory theses of China's capital market. Beijing: Social Science Academy Press, 211-236(in Chinese)

Zhou Jianbo, Sun Jusheng (2003). Study on the governance effect of manager stock incentives. Economic Research Journal, (5): 74-82(in Chinese) 